\title{
GENETIC SUSCEPTIBILITY OF TRANSCRIPTION FACTOR 7-LIKE 2 GENE VARIANT AND RISK OF TYPE 2 DIABETES IN ASIAN INDIANS
}

\author{
NAVNEET KAUR ${ }^{1}$, GURJIT KAUR BHATTI' ${ }^{2}$, SANJAY KUMAR BHADADA ${ }^{3}$, SAMER SINGH ${ }^{4}$, \\ JASVINDER SINGH BHATTI ${ }^{1 *}$
}

\begin{abstract}
${ }^{1}$ Department of Biotechnology, Sri Guru Gobind Singh College, Chandigarh, India. ${ }^{2}$ Department of Medical Lab Technology, University Institute of Applied Health Sciences, Chandigarh University, Mohali, Punjab, India. ${ }^{3}$ Department of Endocrinology, Postgraduate Institute of Medical Education and Research, Chandigarh, India. ${ }^{4}$ Department of Microbial Biotechnology, Panjab University, Chandigarh, India.
\end{abstract} Email: jasvinderbhatti@yahoo.com

Received: 18 February 2019, Revised and Accepted: 30 March 2019

ABSTRACT

Objectives: The variants of transcription factor 7-like 2 (TCF7L2) gene have been shown to be associated with type 2 diabetes mellitus (T2DM) and its related complications.

We aimed to explore the possible association of rs7903146 (C/T) variant in TCF7L2 with the risk of T2DM in the North Indian population.

Methods: The present case-control study included a total of 638 human subjects (318 T2DM subjects and 320 healthy controls). Various anthropometric, biochemical, and genetic parameters were studies in all the subjects. Genotyping of TCF7L2 gene was carried out using allele-specific polymerase chain reaction method.

Results: The results of this study indicate significantly higher values of body mass index, waist circumference, waist-to-hip ratio, and body fat (\%) in T2DM subjects than controls ( $\mathrm{p} \leq 0.001)$. Dyslipidemia represented by higher levels of triglycerides and reduced values of high-density lipoprotein was more predominant in diabetic subjects compared to healthy subjects. The frequency of risk genotype (TT) frequency was significantly higher in T2DM subjects (16.4\%) compared to controls (11.6\%). The " $\mathrm{T}$ " allele was more dominant in diabetic subjects than controls. Logistic regression analysis of the data revealed a significant association of TT genotype with 2-fold (odds ratio with 95\% of confidence interval; 2.09 [1.29-3.42] p=0.003) and CT genotype with 1.7 -fold $(1.73$ [1.23-2.44] p=0.002) increased risk of developing T2DM.

Conclusions: The present study demonstrated a significant association of rs7903146 (C/T) variant in TCF7L2 with the augmented risk of T2DM in North Indian population.

Keywords: Single-nucleotide polymorphism, Transcription factor 7-like 2, Type 2 diabetes mellitus, Insulin resistance, Asian Indians.

(c) 2019 The Authors. Published by Innovare Academic Sciences Pvt Ltd. This is an open access article under the CC BY license (http://creativecommons. org/licenses/by/4. 0/) DOI: http://dx.doi.org/10.22159/ajpcr.2019.v12i5.33130

\section{INTRODUCTION}

Type 2 diabetes mellitus (T2DM) is one of the most challenging problems of the $20^{\text {th }}$ century. T2DM is characterized by hyperglycemia, impaired insulin secretion or insulin resistance, is the most common type of diabetes accounting $90-95 \%$ of total diabetic cases. The prevalence of T2DM is rising rapidly across the globe posing significant socioeconomic burden in the form of lost productivity and stress on health-care system, both in developed and developing countries [1]. At present, T2DM affects 285 million people all over the world and is predicted to rise to 642 million by 2040 globally [2]. At present, India has 85 million individuals suffering from T2DM; however, this number is expected to rise to 109 million by 2035 [3]. India has become diabetic capital of the world. About $80 \%$ of the diabetic population lives in low- and middle-income countries. T2DM is a very complex metabolic disease in which both genetic and environmental factors play an important role in their pathophysiology [4]. The recent advancement in technology had made it possible to identify new genetic loci as well as genes associated with the risk of the development of T2DM. These genetic determinants can be used to better understanding of the pathogenesis of a disease, help in the development of policies to counter the economic burden, and provide a new way for improved and preventive therapeutic measures.

Transcription factor 7-like 2 (TCF7L2) gene is located on the long arm of chromosome 10q25.3 and involved in Wnt signaling pathway which plays a pivotal role in cell development and growth regulation [5]. The previous studies established TCF7L2 gene as possible determinants of type 2 diabetes [6,7]. Although several single-nucleotide polymorphisms (SNPs) in TCF7L2 gene have been replicated in different population and ethnicities, few studies have been done in Indian population. Furthermore, genetic association of TCF7L2 gene has not yet been explored in North Indian population. Hence, the present study was planned to investigate the association of rs7903146 (C/T) variant in TCF7L2 with the risk of T2DM in North Indian population.

\section{METHODS}

\section{Study population}

The present study included 638 participants (318 T2DM patients and 320 healthy controls) recruited from North Indian population. The diagnosis of T2DM was done using criteria established by the American Diabetes Association as follows: A medical record indicating either a fasting glucose levels $>7.0 \mathrm{mmol} / \mathrm{l}$ or $>126 \mathrm{mg} / \mathrm{dl}$ after a minimum 12-h fast or 2-h post-glucose level (oral glucose tolerance test or 2 -h) $>11.1 \mathrm{mmol} / \mathrm{l}$ or $>200 \mathrm{mg} / \mathrm{dl}$ on more than one occasion with symptoms of diabetes. All procedures performed in studies involving human participants were in accordance with the ethical standards of the institutional and/or national research committee and with the 1964 Helsinki Declaration and its later amendments or comparable ethical standards. This study was ethically approved by the Institutional Ethics Committees of Post Graduate Institute of Medical Education 
and Research, Chandigarh and Panjab University, Chandigarh, India. A model consent form adhering to Indian, and International guidelines regarding the use of human subjects were used along with detailed questionnaire of details regarding demographic and socioeconomic characteristics. The participant's self-reported age, sex, educational status, physical activity, dietary habits, family history of the disease and individual's smoking and alcohol use, etc., were recorded.

\section{Anthropometric measurements}

Standard anthropometric measurements were performed including stature, weight, and waist and hip circumferences. Body mass index (BMI) was calculated according to Quetelet equation (BMI = weight in kilograms/height in meters squared). Waist-to-hip ratio (WHR) was calculated as ratio of abdomen to hip circumferences. Blood pressure (BP) was measured using Omron's BP machine in a sitting position, from the left arm resting on the table, with legs uncrossed and feet flat.

The abdominal obesity was measured according to the new cutoffs proposed for South Asian Indians as mentioned in our previous study [8], i.e., WHR $>0.89$ for men and $>0.81$ for women. BMI $<23 \mathrm{~kg} / \mathrm{m}^{2}$ has been proposed for low risk, $23-27.5 \mathrm{~kg} / \mathrm{m}^{2}$ for increased risk, and $\geq 27.5 \mathrm{~kg} / \mathrm{m}^{2}$ for high risk for developing weight-related diseases in Asian populations.

\section{Clinical parameters}

Venous blood samples were extracted from each subject after $12 \mathrm{~h}$ of fasting. A serum sample was analyzed for fasting serum glucose, creatinine, and lipid profile (triglycerides [TG], total cholesterol [TC], high-density lipoprotein cholesterol [HDL-C], and low-density lipoprotein cholesterol [LDL-C]). Fasting and random blood glucose levels were measured using a portable glucometer (Abbott Optium Xceed, USA).

\section{Genotyping of TCF7L2 gene}

The genomic DNA was isolated from the blood using salting out method [9]. DNA yield was measured by absorbance at $260 \mathrm{~nm}$ and purity was checked by calculating $A_{260} / A_{280}$. Amplification of rs7903146 polymorphism in TCF7L2 gene was carried out using allele-specific polymerase chain reaction (PCR) as described in an earlier study [10]. Genotyping was based on differential amplification due to the presence of mismatches. In rs7903146 genotyping, two forward primers with a mismatch in their last 3' nucleotide such a way that each is specific for one of the two variants of the polymorphism and a common reverse primer was used. The forward primers also contain a second mismatch at the third nucleotide from the $3^{\prime}$ end to enhance PCR specificity. The forward primers (rs7903146 C or rs7903146 T) specific for allele C detection: 5'GAACAATTAGAGA GCTAAGCACTTTTTAGAAAC 3 ' and forward primer for allele T detection: 5 'GAACAATTAGAGAGCTAAGCACTTTTTAGAGAT 3', and common reverse primer (rs7903146 R) 5` AGATGAAATGTAGCAGTGAAGTGC 3 ' were combined in two parallel PCR reactions one with primers rs7903146 C and rs7903146 R (PCR C) and a second with primers rs7903146 T and rs7903146 R (PCR T). For each sample, two PCR reactions were run in parallel, one with primers rs7903146 C and rs7903146 R (PCR C) and a second with primers rs7903146 T and rs7903146 R (PCR T) each containing 200 ng genomic DNA, 1X Taq polymerase buffer, $1.5 \mathrm{mM} \mathrm{MgCl}, 10 \mathrm{pmol}$ of each primer, $200 \mu \mathrm{mol} / \mathrm{l}$ dNTPs, and 1U of Taq DNA polymerase (Thermo) in a final volume of $25 \mu$ l. DNA amplification was carried out on thermal cycler (Eppendorf Mastercycler Nexus Gradient) with an initial denaturation for $3 \mathrm{~min}$ at $94^{\circ} \mathrm{C}$, followed by 32 cycles of $1 \mathrm{~min}$ at $94^{\circ} \mathrm{C}, 1 \mathrm{~min}$ at $50^{\circ} \mathrm{C}$, and $1 \mathrm{~min}$ at $72^{\circ} \mathrm{C}$ and final extension for $5 \mathrm{~min}$ at $72^{\circ} \mathrm{C}$. Fig. 1 shows the amplified PCR products separated on $1.5 \%$ agarose gel electrophoresis.

\section{Statistical analysis}

Results were expressed as mean \pm standard deviation. Chi-square analysis was applied to test the significance of differences in genotypic and allelic frequencies. Group comparisons were done using unpaired t-tests. $p<0.05$ (two tailed) was considered as statistically significant

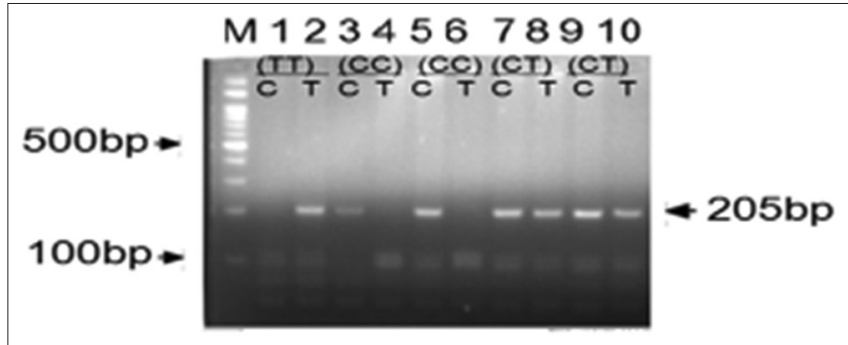

Fig. 1: Agarose gel electrophoresis of transcription factor 7-like 2 (rs7903146C/T) gene polymorphism. Lane M: 100 bp marker ladder; lanes $(1,2)(5,6)$ : CG genotype; lanes $(3,4)$ : GC genotype; lanes $(7,8)(9,10)$ : GG genotype

difference. Logistic regression analyses were performed to calculate odds ratio (OR) and 95\% confidence intervals (CIs) for each risk factor. Statistical analysis was performed using IBM-SPSS for Windows, version 20 (SPSS, Inc., Chicago, IL).

\section{RESULTS}

Clinical and biochemical characteristics of the study subjects Table 1 shows the clinical and biochemical characteristics of the study subjects. There was a no significant difference in the age of the diabetic and control subjects $(47.13 \pm 11.7$ vs. $55.3 \pm 11.3, p=0.001)$. T2DM subjects show predominant abdominal obesity reflected by significantly higher values of BMI $(26.9 \pm 4.6$ vs. $25.9 \pm 4.7, \mathrm{p}=0.02)$, waist circumference $(93.1 \pm 10.5$ vs. $88.1 \pm 10.8, p=0.001)$, and waist to hip circumference $(0.96 \pm 0.06$ vs. $0.93 \pm 0.08, p=0.001)$. No significant difference in body fat percent was observed in T2DM subjects compared to controls $(33.7 \pm 10.3$ vs. $32.7 \pm 9.1)$. Although TC levels fall under the limit of borderline, there is no significant difference between diabetic and non-diabetic controls. Significantly higher values of TG and reduced values of HDL were reported in diabetic patients than controls. Along with abdominal obesity evidenced by higher BMI and WHR, 12\% of patients were having dyslipidemia and were on lipid-lowering drugs. Alterations in clinical and anthropometric measurements pretend a risk for the development of cardiac diseases as demonstrated by higher TC/HDL, LDL/HDL, and TG/HDL ratio in diabetic subjects compared to healthy controls (Table 1).

\section{Association of TCF7L2 gene polymorphisms with T2DM}

The distribution of genotype and allelic frequencies for rs7903146 polymorphisms of TCF7L2 gene are shown in Table 2. TCF7L2 rs7903146 gene polymorphism analysis demonstrated that the frequency of risk genotype TT genotype was significantly higher in diabetics than in controls (16.4\% vs. $11.6 \%)$. The frequency of the "T" allele was significantly higher in diabetic subjects (42\%) compared with that in the healthy control subjects (33\%). Furthermore, CT genotype frequency was more predominant in T2DM subjects $(51.3 \%)$ than control subjects (42.2\%). Logistic regression analysis of the data demonstrated a significant association of TT genotype with 2 -fold (OR with $95 \%$ of CI; 2.09 [1.29-3.42] p=0.003) and CT genotype with 1.7 fold (1.73 [1.23-2.44] $\mathrm{p}=0.002)$ increased risk of developing T2DM in this population. Under a dominant model of inheritance, $\mathrm{T}$ allele shows a significant association with type 2 diabetes (OR, 1.79 $[1.30-2.47] \mathrm{p}=0.0004)$. Furthermore, no significant association was observed with T2DM under recessive model of inheritance (1.49 [0.95-2.35] $\mathrm{p}=0.08)$.

Table 3 summarizes the comparison of clinical and biochemical characteristics of T2DM and control subjects according to different genotypes of TCF7L2 rs7903146. There were no significant differences in metabolic characteristics such as glucose, BMI, WC, WHR, body fat (\%), systolic BP, diastolic BP, TC, TG, HDL, LDL, very LDL, and creatinine among T2DM as well as control subjects carrying CC, CT, and TT genotypes of rs7903146 polymorphisms in TCF7L2 gene. 
Table 1: Comparison of anthropometric and clinical characteristics of the study subjects

\begin{tabular}{|c|c|c|c|}
\hline \multirow[t]{2}{*}{ Parameters } & \multirow{2}{*}{$\begin{array}{l}\text { Controls } \\
\text { Mean } \pm \text { SD }\end{array}$} & \multirow{2}{*}{$\begin{array}{l}\text { T2DM patients } \\
\text { Mean } \pm \text { SD }\end{array}$} & \multirow[t]{2}{*}{ p-value } \\
\hline & & & \\
\hline BMI $\left(\mathrm{kg} / \mathrm{m}^{2}\right)$ & $25.99 \pm 4.7$ & $26.87 \pm 4.6$ & $0.02 *$ \\
\hline Hip $(\mathrm{cm})$ & $95.18 \pm 10.1$ & $96.91 \pm 10.3$ & $0.03^{*}$ \\
\hline WHR & $0.93 \pm 0.08$ & $0.96 \pm 0.06$ & $0.00 *$ \\
\hline Body fat (\%) & $32.69 \pm 9.1$ & $33.71 \pm 10.3$ & 0.18 \\
\hline SBP (mmHg) & $115.97 \pm 8.2$ & $130.78 \pm 15.3$ & $0.00 *$ \\
\hline DBP (mmHg) & $75.94 \pm 6.6$ & $79.81 \pm 10.4$ & $0.00 *$ \\
\hline Glucose (mg/dl) & $92.26 \pm 11.0$ & $146.49 \pm 53.2$ & $0.00 *$ \\
\hline $\mathrm{TC}(\mathrm{mg} / \mathrm{dl})$ & $177.69 \pm 31.6$ & $183.33 \pm 48.7$ & 0.10 \\
\hline $\mathrm{TG}(\mathrm{mg} / \mathrm{dl})$ & $149.50 \pm 55.2$ & $172.49 \pm 87.7$ & $0.00 *$ \\
\hline HDL-C (mg/dl) & $44.77 \pm 6.2$ & $42.21 \pm 7.3$ & $0.00 *$ \\
\hline LDL-C (mg/dl) & $103.02 \pm 28.3$ & $106.62 \pm 42.8$ & 0.23 \\
\hline VLDL-C (mg/dl) & $29.90 \pm 11.0$ & $34.50 \pm 17.5$ & $0.00 *$ \\
\hline Creatinine (mg/dl) & $0.81 \pm 0.6$ & $0.88 \pm 0.4$ & 0.14 \\
\hline Total lipids (mg/dl) & $504.87 \pm 102.7$ & $539.15 \pm 158.8$ & $0.00 *$ \\
\hline Castelli's risk index II (LDL/HDL) & $2.36 \pm 0.8$ & $2.61 \pm 1.2$ & $0.00 *$ \\
\hline Atherogenic coefficient (TG/HDL) & $3.42 \pm 1.4$ & $4.27 \pm 2.4$ & $0.00 *$ \\
\hline Atherogenic index & $0.50 \pm 0.2$ & $0.57 \pm 0.2$ & $0.00 *$ \\
\hline
\end{tabular}

Data values are represented as mean \pm SD. BMI: Body mass index, SBP: Systolic blood pressure, DBP: Diastolic blood pressure, TC: Total cholesterol, HDL-C: High-density lipoprotein cholesterol, LDL: Low-density lipoprotein, VLDL: Very low-density lipoprotein, WHR: Waist-to-hip ratio, T2DM: Type 2 diabetes mellitus, TG: Triglyceride, SD: Standard deviation. *Significant difference between T2DM and control subjects. $p<0.05$ is considered as statistically significant value

Table 2: Test of association depicting TCF7L2 (rs7903146) gene polymorphism as a risk for T2DM in North Indian population

\begin{tabular}{|c|c|c|c|c|}
\hline \multirow[t]{2}{*}{ Genotypes } & \multicolumn{2}{|c|}{ Human participants } & \multicolumn{2}{|l|}{ Test of association } \\
\hline & Controls & T2DM patients & Odds ratio ( $95 \%$ of $\mathrm{CI})$ & Pearson Chi-square \\
\hline $\mathrm{CC}$ & $148(46.2 \%)$ & $103(32.4 \%)$ & Reference & \\
\hline TT & $37(11.6 \%)$ & $52(16.4 \%)$ & $2.09(1.29-3.42) \mathrm{p}=0.003$ & 9.01 \\
\hline Total & 320 & 318 & & \\
\hline Allele C & 0.67 & 0.58 & & \\
\hline Allele T & 0.33 & 0.42 & & \\
\hline \multicolumn{5}{|c|}{ Dominant model (CC vs. CT+TT) } \\
\hline $\mathrm{CC}$ & 148 & 103 & & \\
\hline $\mathrm{CT}+\mathrm{TT}$ & 172 & 215 & $1.79(1.30-2.47) \mathrm{p}=0.0004$ & 12.84 \\
\hline \multicolumn{5}{|c|}{ Recessive model (CC+CT vs. TT) } \\
\hline $\mathrm{CC}+\mathrm{CT}$ & 283 & 266 & & \\
\hline $\mathrm{TT}$ & 37 & 52 & $1.49(0.95-2.35) \mathrm{p}=0.08$ & 3.05 \\
\hline
\end{tabular}

Data are presented as number (\%) unless otherwise stated. T2DM: Type 2 diabetes mellitus, CI: Confidence interval, TCF7L2: Transcription factor 7-like 2. p<0.05 is considered as statistically significant value

\section{DISCUSSION}

India is currently experiencing an epidemic of DM. Both environmental and genetic factors contribute to the development of insulin resistance and type 2 diabetes $[11,12]$. It is evident from the previous studies that several genetic determinants are associated with increased risk of type 2 diabetes, but their conclusive role is still unclear [13]. TCF7L2 gene is considered one of the most important candidate genes for T2DM, playing a key role in blood glucose homeostasis and beta-cell function [14]. TCFL2 encodes a basic helix-loop-helix TCF-4, which acts as a nuclear receptor for the Wnt/ $\beta$-catenin pathway [15] and can preferentially bind to Wnt-responsive elements in genes induced by $\beta$-catenin [16]. It is well known that the $\beta$-catenin/TCF-4 complex participates in various biological events. Particularly, the complex has been found to have an important role in pancreas islet cell proliferation and differentiation and thus contributes to T2DM initiation and progression.

Following the initial report by Grant et al. [17] showing that TCF7L2 variants were strongly associated with T2DM risk, several other studies consistently replicated this association in different ethnicities [6]. The present case-control study established the association of 2 -fold increased diabetes risk with TT homozygous, while CT heterozygous carried 1.7- fold increase in T2DM risk when compared with CC homozygous of rs7903146 polymorphisms in the TCF7L2 gene. Bodhini et al. observed a significant association between the $\mathrm{T}$ allele of rs7903146(C/T) SNPs and T2DM in South Indians [18]. Chandak et al. also observed a strong association of rs7903146 polymorphism with T2DM (OR=1.46) [19]. A previous study revealed a positive significant association between TT genotype of rs7903146 (C/T) variant of TCF7L2 gene and diabetes-related complications in Indian population [20]. Several studies conducted in other parts of the world demonstrated significant relationship between TCF7L2 gene and T2DM in British [21], the US [22], Finnish [23], Amish [24], Scandinavian [25], Polish [25], French [26], Dutch Breda [27], European Whites, migrant Asian Indian, AfroCaribbean [28], Northern Swedish [29], and Japanese populations [30]. A large meta-analysis study confirmed the association of TCF7L2 gene with T2DM in different ethnicities [31]. Our results are similar with the results from the overall meta-analysis of the rs7903146 polymorphism wherein heterozygous genotype CT carried over a 1.4-fold increased risk for T2DM, while TT homozygous carried near a 2.0-fold increase in T2DM risk when compared with CC homozygous. Another metaanalysis study examining 66 studies also confirmed the association of the rs7903146 SNPs with T2DM in 66 studies (OR $=1.41,95 \%$ CI 1.37-1.46 for the T allele) [32]. A similar meta-analysis study in Chinese population also reflected the role of rs7903146(C/T) SNP towards 
Table 3: Metabolic characteristics stratified according to the genotypes of TCF7L2 rs7903146 polymorphism in controls and T2DM subjects

\begin{tabular}{|c|c|c|c|c|c|c|c|c|}
\hline \multirow[t]{3}{*}{ Parameters } & \multicolumn{4}{|c|}{ Control subjects } & \multicolumn{4}{|c|}{ T2DM subjects } \\
\hline & \multirow{2}{*}{$\begin{array}{l}\text { CC }(n=148) \\
\text { Mean } \pm S D\end{array}$} & \multirow{2}{*}{$\begin{array}{l}\text { CT }(n=135) \\
\text { Mean } \pm S D\end{array}$} & \multirow{2}{*}{$\begin{array}{l}\text { TT }(n=37) \\
\text { Mean } \pm S D\end{array}$} & \multirow[t]{2}{*}{ p value } & \multirow{2}{*}{$\begin{array}{l}C C(n=103) \\
\text { Mean } \pm S D\end{array}$} & \multirow{2}{*}{$\begin{array}{l}\text { CT }(n=163) \\
\text { Mean } \pm S D\end{array}$} & \multirow{2}{*}{$\begin{array}{l}\text { TT }(n=54) \\
\text { Mean } \pm S D\end{array}$} & \multirow[t]{2}{*}{ p-value } \\
\hline & & & & & & & & \\
\hline BMI $\left(\mathrm{kg} / \mathrm{m}^{2}\right)$ & $25.61 \pm 4.8$ & $26.37 \pm 4.6$ & $26.17 \pm 4.4$ & 0.381 & $26.46 \pm 4.8$ & $27.19 \pm 4.5$ & $26.71 \pm 4.2$ & 0.428 \\
\hline $\mathrm{WC}(\mathrm{cm})$ & $88.96 \pm 11.3$ & $87.58 \pm 10.3$ & $86.94 \pm 10.8$ & 0.437 & $91.72 \pm 9.8$ & $93.64 \pm 11.5$ & $94.33 \pm 8.5$ & 0.235 \\
\hline Hip (cm) & $94.74 \pm 10.0$ & $95.78 \pm 10.5$ & $94.71 \pm 9.4$ & 0.664 & $95.47 \pm 9.4$ & $97.82 \pm 11.2$ & $96.93 \pm 8.8$ & 0.193 \\
\hline WHR & $0.94 \pm 0.08$ & $0.92 \pm 0.1$ & $0.92 \pm 0.07$ & 0.033 & $0.96 \pm 0.1$ & $0.96 \pm 0.1$ & $0.97 \pm 0.1$ & 0.245 \\
\hline SBP (mmHg) & $116.22 \pm 8.1$ & $115.68 \pm 6.9$ & $116.03 \pm 12.1$ & 0.859 & $130.85 \pm 15.2$ & $130.07 \pm 15.9$ & $132.85 \pm 13.7$ & 0.524 \\
\hline DBP (mmHg) & $75.53 \pm 6.7$ & $76.59 \pm 6.7$ & $75.17 \pm 6.1$ & 0.313 & $80.91 \pm 13.7$ & $79.26 \pm 8.7$ & $79.33 \pm 7.4$ & 0.424 \\
\hline Glucose (mg/dl) & $91.98 \pm 10.4$ & $93.07 \pm 11.2$ & $90.46 \pm 12.4$ & 0.427 & $151.56 \pm 58.1$ & $142.31 \pm 51.5$ & $149.76 \pm 47.7$ & 0.349 \\
\hline $\mathrm{TC}(\mathrm{mg} / \mathrm{dl})$ & $177.99 \pm 31.5$ & $177.51 \pm 31.4$ & $177.12 \pm 33.6$ & 0.986 & $177.73 \pm 47.1$ & $185.59 \pm 51.4$ & $187.46 \pm 42.4$ & 0.387 \\
\hline $\mathrm{TG}(\mathrm{mg} / \mathrm{dl})$ & $154.87 \pm 62.6$ & $146.02 \pm 48.0$ & $140.56 \pm 46.5$ & 0.26 & $171.86 \pm 81.8$ & $175.57 \pm 97.2$ & $163.38 \pm 63.1$ & 0.713 \\
\hline HDL-C (mg/dl) & $44.51 \pm 6.1$ & $44.68 \pm 5.5$ & $46.13 \pm 9.0$ & 0.391 & $42.23 \pm 6.6$ & $42.41 \pm 7.5$ & $41.50 \pm 8.0$ & 0.765 \\
\hline LDL-C (mg/dl) & $102.51 \pm 28.1$ & $103.62 \pm 27.7$ & $102.87 \pm 32.0$ & 0.95 & $101.13 \pm 42.9$ & $108.07 \pm 44.3$ & $113.28 \pm 36.9$ & 0.244 \\
\hline VLDL-C (mg/dl) & $30.97 \pm 12.5$ & $29.20 \pm 9.6$ & $28.11 \pm 9.3$ & 0.26 & $34.37 \pm 16.4$ & $35.11 \pm 19.4$ & $32.68 \pm 12.6$ & 0.713 \\
\hline Creatinine (mg/dl) & $0.85 \pm 0.9$ & $0.77 \pm 0.3$ & $0.81 \pm 0.3$ & 0.608 & $0.86 \pm 0.4$ & $0.91 \pm 0.5$ & $0.81 \pm 0.5$ & 0.373 \\
\hline
\end{tabular}

Data values are written as mean \pm SD, SBP: Systolic blood pressure, DBP: Diastolic blood pressure, TC: Total cholesterol, TG: Triglyceride, WC: Waist circumference, WHR: Waist-to-hip ratio, BMI: Body mass index, HDL: High-density lipoprotein, LDL: Low-density lipoprotein, VLDL: Very low-density lipoprotein,

TCF7L2: Transcription factor 7-like 2, SD: Standard deviation

increased susceptibility to T2DM (OR $=1.54,95 \%$ CI 1.37 - 1.74 for the $\mathrm{T}$ allele) [33]. A study by Lou et al. indicated that four SNPs of TCF7L2 (rs7903146, rs12255372, rs11196205, and rs290487) were associated with T2DM risk in East Asian [34]. Eight TCF7L2 polymorphisms in 155 studies with 121,174 subjects $(53,385$ cases and 67,789 controls $)$ were addressed in their meta-analysis. Significant association was established between T2DM risk and rs7903146 and many other polymorphisms in TCF7L2 gene under an additive inheritance model.

The present study did not find any link between SNP rs7903146 and abnormalities in cardiometabolic traits including BMI, WHR, and dyslipidemia. Similar results were observed in the previous studies conducted in India. Chandak et al. observed no significant association with BMI or WHR in T2DM patients or control subjects [19]. Also, no significant difference in respect to metabolic parameters between different genotypes of rs7903146(C/T was observed [36]. Contrary, many studies show the association of TCF7L2 gene polymorphism with many metabolic traits $[6,17,35-38]$. Cauchi et al. found that the T allele of rs7903146 predicts hyperglycemia in French population [26]. Saxena et al. found that individuals homozygous for the rs7903146 risk allele had a significant reduction in insulinogenic index and insulin disposition index [25]. Damcott et al. found significant association with insulin sensitivity index, acute insulin response to glucose in non-Amish Caucasian subjects [24]. Our results showed that the rs7903146 T allele of the TCF7L2 gene was positively correlated with an enhanced risk of T2DM in codominant and dominant models of inheritance.

\section{CONCLUSIONS}

The present study confirms the association of rs7903146 (C/T) polymorphism in TCF7L2 gene with risk of T2DM in North Indian population. However, no significant influence of this polymorphism was observed with cardiometabolic traits.

\section{ACKNOWLEDGMENTS}

The support for this study was provided by University Grant Commission, India. NK was financially supported under INSPIRE fellowship by DST, Govt. of India.

\section{AUTHORS' CONTRIBUTIONS}

Study design and implementation: GKB, SS, SKB, and JSB. Data collection and analysis: GKB and SKB. Manuscript drafting: NK, GKB, and JSB. Manuscript revisions: All authors.

\section{CONFLICTS OF INTEREST}

The authors have no conflicts of interest to declare.

\section{REFERENCES}

1. van Dieren S, Beulens JW, van der Schouw YT, Grobbee DE, Neal B. The global burden of diabetes and its complications: An emerging pandemic. Eur J Cardiovasc Prev Rehabil 2010;17 Suppl 1:S3-8.

2. Ogurtsova K, da Rocha Fernandes JD, Huang Y, Linnenkamp U, Guariguata L, Cho NH, et al. IDF diabetes atlas: Global estimates for the prevalence of diabetes for 2015 and 2040. Diabetes Res Clin Pract 2017; $128: 40-50$

3. International Diabetes Federation. IDF Diabetes Atlas. $8^{\text {th }}$ ed. International Diabetes Federation; 2017. Available from: https://www. idf.org/our-activities/advocacy-awareness/resources-and-tools/134:idfdiabetes-atlas-8th-edition.html.

4. Bhatti GK, Bhadada SK, Vijayvergiya R, Mastana SS, Bhatti JS. Metabolic syndrome and risk of major coronary events among the urban diabetic patients: North indian diabetes and cardiovascular disease study-NIDCVD-2. J Diabetes Complications 2016;30:72-8.

5. Duval A, Busson-Leconiat M, Berger R, Hamelin R. Assignment of the TCF-4 gene (TCF7L2) to human chromosome band 10q25.3. Cytogenet Cell Genet 2000;88:264-5.

6. Florez JC, Jablonski KA, Bayley N, Pollin TI, de Bakker PI, Shuldiner AR, et al. TCF7L2 polymorphisms and progression to diabetes in the diabetes prevention program. N Engl J Med 2006;355:241-50.

7. Ingelsson E, Langenberg C, Hivert MF, Prokopenko I, Lyssenko V, Dupuis $\mathrm{J}$, et al. Detailed physiologic characterization reveals diverse mechanisms for novel genetic loci regulating glucose and insulin metabolism in humans. Diabetes 2010;59:1266-75.

8. Bhatti GK, Kaur S, Vijayvergiya R, Bhadada SK, Mastana SS, Singh B, et al. ENPP1 K121Q functional variant enhances susceptibility to insulin resistance and dyslipidemia with metabolic syndrome in Asian Indians. Int J Diabetes Metab 2018;21:8-15.

9. Miller SA, Dykes DD, Polesky HF. A simple salting out procedure for extracting DNA from human nucleated cells. Nucleic Acids Res 1988;16:1215.

10. Dutra LA, Costa PG, Velasco LF, Amato AA, Barra GB. Allele-specific PCR assay to genotype SNP rs7903146 in TCF7L2 gene for rapid screening of diabetes susceptibility. Arq Bras Endocrinol Metabol 2008;52:1362-6

11. Bhatti JS, Joshi A, Mastana S, Bansal D, Bhatti GK, Rai S, et al. Identification of the risk factors for the high prevalence of Type 2 diabetes and its complications in a Punjabi population: North indian diabetes study: A case-control study. Int $\mathrm{J}$ Diabetes Dev Ctries 2007;27:108-15.

12. Arafat M, Salam A, Arafat O. The association of Type 2 diabetes with 
obesity and other factors: In multinational community. Int J Pharm Pharm Sci 2014;6:257-60

13. Haghighatpanah M, Leiter LA, Ceriello A, Davidson JA, Hanefeld M, Monnier L, et al. Correlation of glycosylated hemoglobin levels with fasting and postprandial glucose in south Indian Type 2 diabetic patients. Int J Pharm Pharm Sci 2016;8:285-8.

14. Jyothi KU, Jayaraj M, Subburaj KS, Prasad KJ, Kumuda I, Lakshmi V, et al. Association of TCF7L2 gene polymorphisms with T2DM in the population of Hyderabad, India. PLoS One 2013;8:e60212.

15. Smith U. TCF7L2 and Type 2 diabetes we WNT to know. Diabetologia 2007;50:5-7

16. Gougelet A, Torre C, Veber P, Sartor C, Bachelot L, Denechaud PD, et al. T-cell factor 4 and $\beta$-catenin chromatin occupancies pattern zonal liver metabolism in mice. Hepatology 2014;59:2344-57.

17. Grant SF, Thorleifsson G, Reynisdottir I, Benediktsson R, Manolescu A, Sainz J, et al. Variant of transcription factor 7-like 2 (TCF7L2) gene confers risk of Type 2 diabetes. Nat Genet 2006;38:320-3

18. Bodhini D, Radha V, Dhar M, Narayani N, Mohan V. The rs $12255372(\mathrm{G} / \mathrm{T})$ and $\mathrm{rs} 7903146(\mathrm{C} / \mathrm{T})$ polymorphisms of the TCF7L2 gene are associated with Type 2 diabetes mellitus in Asian Indians. Metabolism 2007;56:1174-8

19. Chandak GR, Janipalli CS, Bhaskar S, Kulkarni SR, Mohankrishna P, Hattersley AT, et al. Common variants in the TCF7L2 gene are strongly associated with Type 2 diabetes mellitus in the Indian population. Diabetologia 2007;50:63-7.

20. Singh K, Agrawal NK, Gupta SK, Singh K. Association of variant rs7903146 (C/T) single nucleotide polymorphism of TCF7L2 gene with impairment in wound healing among North Indian Type 2 diabetes population: A case-control study. Int J Low Extrem Wounds 2013; $12: 310-5$

21. Groves CJ, Zeggini E, Minton J, Frayling TM, Weedon MN, Rayner NW, et al. Association analysis of 6,736 U.K. Subjects provides replication and confirms TCF7L2 as a Type 2 diabetes susceptibility gene with a substantial effect on individual risk. Diabetes 2006;55:2640-4

22. Zhang C, Qi L, Hunter DJ, Meigs JB, Manson JE, van Dam RM, et al. Variant of transcription factor 7-like 2 (TCF7L2) gene and the risk of Type 2 diabetes in large cohorts of U.S. Women and men. Diabetes 2006;55:2645-8.

23. Scott LJ, Bonnycastle LL, Willer CJ, Sprau AG, Jackson AU, Narisu N, et al. Association of transcription factor 7-like 2 (TCF7L2) variants with Type 2 diabetes in a finnish sample. Diabetes 2006;55:2649-53.

24. Damcott CM, Pollin TI, Reinhart LJ, Ott SH, Shen H, Silver KD, et al. Polymorphisms in the transcription factor 7-like 2 (TCF7L2) gene are associated with Type 2 diabetes in the amish: Replication and evidence for a role in both insulin secretion and insulin resistance. Diabetes 2006;55:2654-9.

25. Saxena R, Gianniny L, Burtt NP, Lyssenko V, Giuducci C, Sjögren M, et al. Common single nucleotide polymorphisms in TCF7L2 are reproducibly associated with Type 2 diabetes and reduce the insulin response to glucose in nondiabetic individuals. Diabetes
2006;55:2890-5

26. Cauchi S, Meyre D, Dina C, Choquet H, Samson C, Gallina S, et al. Transcription factor TCF7L2 genetic study in the french population: Expression in human beta-cells and adipose tissue and strong association with Type 2 diabetes. Diabetes 2006;55:2903-8.

27. van Vliet-Ostaptchouk JV, Shiri-Sverdlov R, Zhernakova A, Strengman E, van Haeften TW, Hofker MH, et al. Association of variants of transcription factor 7-like 2 (TCF7L2) with susceptibility to Type 2 diabetes in the dutch breda cohort. Diabetologia 2007;50:59-62.

28. Humphries SE, Gable D, Cooper JA, Ireland H, Stephens JW, Hurel SJ, et al. Common variants in the TCF7L2 gene and predisposition to Type 2 diabetes in UK European whites, Indian Asians and afrocaribbean men and women. J Mol Med (Berl) 2006;84:1005-14.

29. Marzi C, Huth C, Kolz M, Grallert H, Meisinger C, Wichmann HE, et al. Variants of the transcription factor 7-like 2 gene (TCF7L2) are strongly associated with Type 2 diabetes but not with the metabolic syndrome in the MONICA/KORA surveys. Horm Metab Res 2007;39:46-52.

30. Horikoshi M, Hara K, Ito C, Nagai R, Froguel P, Kadowaki T, et al. A genetic variation of the transcription factor 7-like 2 gene is associated with risk of Type 2 diabetes in the japanese population. Diabetologia 2007;50:747-51

31. Tong Y, Lin Y, Zhang Y, Yang J, Zhang Y, Liu H, et al. Association between TCF7L2 gene polymorphisms and susceptibility to Type 2 diabetes mellitus: A large human genome epidemiology (HuGE) review and meta-analysis. BMC Med Genet 2009;10:15

32. Song Y, Yeung E, Liu A, Vanderweele TJ, Chen L, Lu C, et al. Pancreatic beta-cell function and Type 2 diabetes risk: Quantify the causal effect using a mendelian randomization approach based on meta-analyses. Hum Mol Genet 2012;21:5010-8

33. Wang J, Hu F, Feng T, Zhao J, Yin L, Li L, et al. Meta-analysis of associations between TCF7L2 polymorphisms and risk of Type 2 diabetes mellitus in the Chinese population. BMC Med Genet $2013 ; 14: 8$

34. Luo Y, Wang H, Han X, Ren Q, Wang F, Zhang X, et al. Meta-analysis of the association between SNPs in TCF7L2 and Type 2 diabetes in East Asian population. Diabetes Res Clin Pract 2009;85:139-46.

35. Gupta V, Khadgawat R, Ng HK, Walia GK, Kalla L, Rao VR, et al. Association of TCF7L2 and ADIPOQ with body mass index, waist-hip ratio, and systolic blood pressure in an endogamous ethnic group of India. Genet Test Mol Biomarkers 2012;16:948-51

36. Mandour I, Darwish R, Fayez R, Naguib M, El-Sayegh S. TCF7L2 gene polymorphisms and susceptibility to Type 2 diabetes mellitus, a pilot study. Biomed Pharmacol J 2018;11:1043-9.

37. Phillips CM, Goumidi L, Bertrais S, Field MR, McManus R, Hercberg $\mathrm{S}$, et al. Dietary saturated fat, gender and genetic variation at the TCF7L2 locus predict the development of metabolic syndrome. J Nutr Biochem 2012;23:239-44.

38. Bodhini D, Gaal S, Shatwan I, Ramya K, Ellahi B, Surendran S, et al. Interaction between TCF7L2 polymorphism and dietary fat intake on high density lipoprotein cholesterol. PLoS One 2017;12:e188382. 